\title{
PROFESSIONAL AND SKILLED OCCUPATIONS
}

\author{
By Kelly Miller, LL.D., \\ Dean, Howard University, Washington, D. C.
}

The world's workers may be divided into two well-defined classes: (1) those who are concerned in the production and distribution of wealth, and (2) those whose function is to regulate the physical, intellectual, moral, spiritual, and social life of the people. The sustaining element includes workers in the field of agriculture, domestic and personal service, trade and transportation, and in manufacturing and mechanical pursuits. The governing class comprises government officials, ministers, teachers, physicians, lawyers, editors, and authors. The great bulk of the population representing the toiling masses is found under the first head, while a comparatively small number is required for the so-called learned professions. In the United States, the two elements are divided in the approximate ratio of twenty to one. Traditionally, these two classes have been separated by a wide and deep social gulf. All honor and glory have attached to the higher professional pursuits, while those who recruited the ranks of the toiling world have been accorded a distinctively lower order of consideration and esteem. The youth who were most highly gifted by nature or favored by fortune naturally sought careers in the genteel professions, leaving those of lesser gifts and limited opportunity to recruit the ranks of the lower order of service. Present tendency, however, is against this hard and fast demarcation. Distinction is made to depend upon success, and success upon efficiency, regardless of the nature of the pursuit or vocation. Honor and shame no longer attach to stated occupations or callings, but depend upon achievement in work rather than in choice of task.

The Negro was introduced into this country for the purpose of performing manual and menial labor. It was thought that, for all time to come, he would be a satisfied and contented hewer of wood, drawer of water and tiller of the soil. He was supposed to represent a lower order of creation, a little more than animal and a little less 
than human. The dominant dogma of that day denied him capacity or aspiration to rise above the lowest level of menial service. $\mathrm{He}$ was deemed destined to everlasting servility by divine decree. His place was fixed and his sphere defined in the cosmic scheme of things. There was no more thought that he would or could ever aspire to the ranks of the learned professions than that like ambition would ever actuate the lower animals. Much of this traditional bias is brought forward and reappears in the present day attitude on the race problem. There still lingers a rapidly diminishing remnant of infallible philosophers who assume intimate acquaintance with the decrees of the Almighty and loudly assert that the Negro is God-ordained to everlasting inferiority. But those who assume foreknowledge with such self-satisfied assurance prudently enough fail to tell us of their secret means of familiarity with the divine plans and purposes. They do not represent the calibre of mind or quality of spirit through which such revelation is usually vouchsafed to man. From this school of opinion, the Negro's aspiration to enter the learned professions is met with ridicule and contempt. The time, money, and effort spent upon the proruction and preparation of this class have been worse than wasted because they tend to subvert the ordained plan. Higher education is decried; industrial education, or rather the training of the hand, is advised, as the hand is considered the only instrument through which the black man can fulfill his appointed mission.

But social forces, like natural laws, pay little heed to the noisome declaration of preconceived opinion. The inherent capacities of human nature will assert themselves despite the denial of the doctrinaire. The advancement of the Negro during the past fifty years has belied every prediction propounded by this doleful school of philosophy. Affirmed impossibilities have come to pass. The "never" of yesterday has become the actuality of today.

In a homogeneous society where there is no racial cleavage, only the select members of the most favored class of society occupy the professional stations. The element representing the social status of the Negro would furnish few members of the coveted callings. The element of race, however, complicates every feature of the social equation. In India, we are told, the population is divided horizontally by caste and vertically by religion. But in America, the race spirit serves as both a horizontal and a vertical separation. 
The Negro is segregated and shut into himself in all social and semisocial relations of life. This isolation necessitates separate ministrative agencies from the lowest to the highest rungs of the ladder of service. During the days of slavery, the interest of the master demanded that he should direct the general social and moral life of the slave. The sudden severence of this tie left the Negro wholly without intimate guidance and direction. The ignorant must be enlightened, the sick must be healed, the poor must have the gospel preached to them, the wayward must be directed, the lowly must be uplifted, and the sorrowing must be solaced. The situation and circumstances under which the race found itself demander that its ministers, teachers, physicians, lawyers, and editors should, for the most part, be men of their own blood and sympathies. The demands for a professional class were imperative. The needed service could not be effectively performed by those who assume and assert racial arrogance and hand down their benefactions as the cold crumbs that fall from the master's table. The help that is to be helpful to the lowly and the humble must come from the horizontal hand stretched out in fraternal good will, and not the one that is pointed superciliously downward. The professional class who are to uplift and direct the lowly and humble must not say "So far shalt thou come but no farther," but rather "Where I am there ye shall be also."

There is no more pathetic chapter in the history of human struggle than the smothered and suppressed ambition of this race in its daring endeavor to meet the greatest social exigency to supply the professional demand of the masses. There was the suddenness and swiftness of leap as when a quantity in mathematics changes signs in passing through zero or infinity. In an instant, in the twinkling of an eye, the plow-hand was transformed into the priest, the barber into the bishop, the house-maid into the school-mistress, the porter into the physician, and the day-laborer into the lawyer. These high places of intellectual and moral authority into which they found themselves thrust by stress of social necessity, had to be operated with at least some semblance of conformity with the standards which had been established by the European through the traditions of the ages. The high places in society occupied by the choicest members of the white race after years of preliminary preparation had to be assumed by men without personal or formal fitness. 
The stronger and more aggressive natures pushed themselves into these high callings by sheer force of untutored energy and uncontrolled ambition. That there would needs be much grotesqueness, mal-adjustment, and failures goes without saying. But after making full allowance for human imperfections, the 50,000 Negroes who now fill the professional places among their race represent a remarkable body of men, and indicate the potency and promise of the race.

The federal census of 1900 furnishes the latest available data of the number of Negroes engaged in the several productive and professional pursuits.

Allowance, of course, must be made for growth in several departments during the intervening thirteen years.

Negroes Engaged in Productive and Distributive Pursuits, 1900

Agriculture ............................ 2,143,154

Domestic and personal service .................. 1.317,859

Trade and transportation .................... 208,989

Manufacturing and mechanical pursuits............ 275,116

Total. . . . . . . . . . . . . . . . . . . . . . . 3,945,118

Negroes Engaged in Professional Service, 1900

Clergymen..................................... $\quad 15,528$

Physicians and surgeons...................... 1,734

Dentists..................................... ${ }_{212}$

Lawyers.................................. $\quad 7_{28}$

Teachers ............................... 21,267

Musicians and teachers of music . . . . . . . . . . . . 3,915

Architects, designers, draughtsmen ................. $\quad 52$

Actors, professional showmen, etc ................ 2,020

Artists and teachers of art..................... $\quad 236$

Electricians............................... $\quad 185$

Engineers and surveyors ....................... $\quad 120$

Journalists ............................... $\quad 210$

Literary and scientific persons . . . . . . . . . . . . . . . . . . $\quad 99$

Government officials.......................... $\quad 645$

Others in professional service................... 268

Total...........................

From these tables it will be seen that only 1 Negro worker in 84 is engaged in professional pursuits. Whereas, 1 white person in 20 is found in this class. According to this standard the Negro has less than one-fourth of his professional quota. 
The Negro ministry was the first professional body to assume full control and direction of the moral and spiritual life of the masses. As soon as the black worshipper gained a conscious sense of selfrespect, which the Christian religion is sure to impart, he became dissatisfied with the assigned seats in the synagogue. The back pews and upper galleries did not seem compatible with the dignity of those who had been baptized into the fellowship and communion of the saints. With the encouragement of the whites, the Negro worshippers soon set up their own separate houses of worship. There arose a priesthood, after the manner of Melchizedek, without antecedent or preparation. But, notwithstanding all their disabilities, these comparatively ignorant and untrained men have succeeded in organizing the entire Negro race into definite religious bodies and denominational affiliations. The Baptist and Methodist denominations, which operate on the basis of ecclesisatical independence, have practically brought the entire race under their spiritual dominion. This is the one conspicuous achievement placed to the credit of the race by way of handling large interests. Passing over the inevitable imperfections in the development of the religious life of the race, the great outstanding fact remains that this vast religious estate, comprising 30,000 church organizations, with a membership of over $3,500,000$ communicants, upon a property basis of $\$ 56,000,000$, has been organized and handed down to the rising generation as its most priceless inheritance. The Negro church is not merely a religious institution, but comprises all the complex features of the life of the people. It furnishes the only field in which the Negro has shown initiative and executive energy on a large scale. There is no other way to reach the masses of the race with any beneficent ministrations except through the organizations that these churches have established. The statesmanship and philanthropy of the nation would do well to recognize this fact. Indeed, it is seriously to be questioned if any belated people, in the present status of the Negro, can be wisely governed without the element of priestcraft. Broadly speaking, the Negro is hardly governed at all by the state, but merely coerced and beaten into obedience. $\mathrm{He}$ is not encouraged to have any comprehensive understanding of or participating hand in the beneficent aims and objects of government. The sheriff and the trial judge are the only government officials with whom he is familiar; and he meets with these only when his life or his property 
is in jeopardy. If it were not for the church, the great mass of the Negro race would be wholly shut off from any organized influence touching them with sympathetic intent. As imperfect as the Negro church must be in many of its features, it is the most potential uplifting agency at work among the people. Eliminate the church, and the masses of the people would speedily lapse into a state of moral and social degeneration worse than that from which they are slowly evolving. The great problem in the uplift of the race must be approached through the pulpit. The Negro preacher is the spokesman and leader of the people. He derives his support from them and speaks, or ought to speak, with the power and authority of the masses. He will be the daysman and peacemaker between the races, and in his hands is the keeping of the key of the destiny of the race. If these 30,000 pulpits could be filled in this generation by the best intelligence, character, and consecration within the race, all of its complex problems would be on a fair way towards solution. The ignorance of the ministry of the passing generation was the kind of ignorance that God utilizes and winks at; but $\mathrm{He}$ will not excuse or wink at its continuance. It is a sad day for any race when the "best they breed" do not aspire to the highest and holiest as well as the most influential callings; but it will be sadder still for a retarded race, if its ministry remains in the hands of those who are illy prepared to exercise its high functions.

The rise of the colored teacher is due to the outcome of the Civil War. The South soon hit upon the plan of the scholastic separation of the races and assigned colored teachers to colored schools as the best means of carrying out this policy. There were at first a great many white teachers mainly from the North, but in time, the task of enlightening the millions of Negro children has devolved upon teachers of their own race. It was inevitable that many of the teachers for whom there was such a sudden demand should be poorly prepared for their work. It was and still is a travesty upon terms to speak of such work as many of them are able to render as professional service.

Among the white race, the teacher has not yet gained the fulness of stature as a member of the learned professions. They do not constitute a self-directing body; both are controlled as a collateral branch of the state or city government, of which they constitute a subordinate part. The ranks are recruited mainly from 
the female sex. In case of the Negro teacher, these limitations are severely emphasized. The orders and directions come from the white superintendent, but there is some latitude of judgment and discretion in a wise and sensible adaptation. The great function of the Negro teacher is found in the fact that she has committed to her the training of the mind, manners, and method of the young who are soon to take their place in the ranks of the citizenship of the nation. While there is wanting the independent scope which the preacher exercises in the domain of moral and spiritual control, nevertheless the teacher exercises a most important function in the immediate matters committed to her. The Negro teacher has the hardest and heaviest burden of any other element of the teaching profession. Education means more to the Negro than it does to the white child who from inheritance and environment gains a certain coefficiency of power aside from the technical acquisition of the school room. The teacher of the Negro child, on the other hand, must impart not only the letter, but also the fundamental meaning of the ways and methods of civilized life. She should have a preparation for work and the fixed consecration to duty commensurate to the imposed task.

The colored doctor has more recently entered the arena. At first, the Negro patient refused to put confidence in the physicians of his own race, notwithstanding the closer intimacy of social contact. It was only after he had demonstrated his competency to treat disease as skillfully as the white practitioner that he was able to win recognition among his own people. The colored physician is still in open competition with the white physician, who never refuses to treat the Negro patient if allowed to assume the disdainful attitude of racial superiority. If the Negro doctor did not secure practically as good results in treating disease as the white practitioner, he would soon find himself without patients. He must be subject to the same preliminary test of fitness for the profession, and must maintain the same standard of efficiency and success. The Negro physicians represent the only body of colored men, who, in adequate numbers, measure up to the full scientific requirements of a learned profession.

By reason of the stratum which the Negro occupies in our social scheme, the race is an easy prey to diseases that affect the health of the whole nation. The germs of disease have no race 
prejudice. They do not even draw the line at social equality. The germ that afflicts the Negro today will attack the white man tomorrow. One touch of disease makes the whole world kin, and also kind. The Negro physician comes into immediate contact with the masses of the race. $\mathrm{He}$ is a sanitary missionary. His ministration is not only to his own race, but to the community and to the nation as a whole. The dreaded white plague which the nation desires to stamp out by concerted action seems to prefer the black victim. The Negro physician is one of the most efficient agencies in helping to stamp out this dread enemy of mankind. His success has been little less than marvelous. In all parts of the country he is rendering efficient service and is achieving both professional and financial success. Educated Negro men are crowding into this profession and will of course continue to do so until the demand has been fully supplied. The race can easily support twice the number of physicians now qualified to practice.

The Negro lawyer has not generally been so fortunate as his medical confrere. The relation between attorney and client is not necessarily close and confidential as that of physician and patient, but is more business-like and formal. The client's interests are also dependent upon the judge and jury with whom the white attorney is sometimes supposed to have greater weight and influence. For such reasons, there are fewer Negroes in the profession of law than in the other so-called learned professions. The Negro lawyer is rapidly winning his way over the prejudice of both races, just as the doctor has had to do. There are to be found in every community examples of the Negro lawyer who has won recognition from both races and who maintains a high standard of personal and professional success. A colored lawyer was appointed by President Taft as assistant attorney-general of the United States, and by universal testimony conducted the affairs of his office with the requisite efficiency and dignity. As Negro enterprises multiply and develop, such as banks, building associations, and insurance companies, and the general prosperity of the people increases, the Negro lawyer will find an increasing sphere of usefulness and influence.

Negroes are also found in all the other professional pursuits and furnish a small quota of editors, engineers, electricians, authors, and artists. Merchants, bankers, and business men are rapidly increasing in all parts of the country. Apprehension is sometimes 
felt that colored men will rush to the learned professions to the neglect of the humbler lines of service. The facts show that the race at present has not more than a fourth of its quota in the professional pursuits. The demand will always regulate the supply. When the demand has been supplied in any profession, the overfow, will seek outlet in unoccupied fields.

The uplift and quickening of the life of the race depends upon the professional classes. The early philanthropist in the Southern field acted wisely in developing leaders among the people. Philanthropy at best can only furnish the first aid and qualify leaders. The leaders must then do the rest. Any race is hopeless unless it develops its own leadership and direction. It is impossible to apply philanthropy to the masses except through the professional classes.

The higher education of the Negro is justified by the requirements of the leaders of the people. It is a grave mistake to suppose that, because the Negro is relatively backward as compared to the white man, his leaders need not have the broadest and best education that our civilization affords. The more backward and ignorant the led, the more skilled and sagacious should the leader be. It requires more skill to lead the helpless than to guide those who need no direction. If the blind lead the blind, they will both fall into the ditch. The professional class constitutes the light of the race. The Negro needs headlight to guide him safely and wisely amid the dangers and vicissitudes of an environing civilization.

The Negro teacher meets with every form of ignorance and pedagogical obtuseness that befalls the white teacher; the Negro preacher has to do with every conceivable form of original and acquired sin; the doctor meets with all the variety of disease that the human flesh is heir to; the lawyer's' sphere covers the whole gamut involving the rights of property and person. The problems involved in the contact, attrition, and adjustment of the races involve issues which are as intricate as any that have ever taxed human wisdom for solution. If, then, the white man who stands in the high place of authority and leadership among his race, fortified as he is by a superior social environment, needs to qualify for his high calling by thorough and sound educational training, surely the Negro needs a no less thorough general education to qualify him to serve as philosopher, guide, and friend of ten million unfortunate human beings. 